\title{
Instant Porridge with Red Beans (Phaseolus vulgaris $L$ ) and Oyster Mushrooms (Pleurotus ostreatus) as A Complementary Feeding
}

\author{
Purbowati $^{1 *}$,Dyah Kartika Wening ${ }^{1}$, Puji Afiatna ${ }^{1}$, Sugeng Maryanto ${ }^{1}$, and Isri Nasifah $^{2}$ \\ ${ }^{1}$ Nutrition Study Program, Faculty of Health, Universitas Ngudi Waluyo, Indonesia \\ ${ }^{2}$ Midwifery Study Program, Faculty of Health, Universitas Ngudi Waluyo, Indonesia
}

\begin{abstract}
Complementary feeding is used for infants aged 6-24 months to meet nutritional needs other than breast milk. The addition of local food ingredients could increase the nutritional value of instant baby porridge, such as red beans and oyster mushrooms, as a source of protein and fiber. This study was conducted to evaluate instant porridge preference and nutritional contents with red beans and oyster mushrooms. Quasiexperiment completely randomized method was used in this study. There were 3 formulations of porridge based on the composition of rice flour and red bean $(60: 40,70: 30$, and 80:20). All formulas were added with 1 gram of dry oyster mushrooms. Based on an organoleptic test conducted by 25 infant mothers, the ratio of 70:30 was the best formula. This formula contained 39.2 grams of carbohydrates, protein 6.1 grams, 1 gram of fat, and 1.1 grams of fiber per serving. Instant porridge formula 2 fulfils the nutritional needs of infants aged 6-12 months of carbohydrates, protein, fat and fiber, respectively $37.3 \%, 40.1 \%, 2.9 \%$, and $10 \%$.
\end{abstract}

\section{Introduction}

Complementary feeding includes solid foods from 6 to 24 months, besides breastmilk, formula, cow's milk, or other liquid substitutes [1]. Complementary feeding could be divided into two groups, complementary commercial foods and homemade. The provision of complementary foods should be made from cheap and accessible materials to obtain and fulfil the nutritional needs and practice good eating habits [2]. The recent report from the Commission on Ending Childhood Obesity focused attention on complementary feeding [3]. It has been estimated that appropriate complementary feeding practices contribute to a 17 per cent reduction in the prevalence of stunting at 24 months of age and could avert 6 per cent of under-five deaths each year [4].

Complementary feeding should be timely (start receiving from 6 months onward) and adequate (in amounts, frequency, consistency, and using a variety of foods). The foods should be prepared and given safely and be given in a way that is appropriate (foods are of appropriate texture for the child's age) and applying responsive feeding following principles for psychosocial care [5]. Complementary foods should have a texture and consistency that

* Corresponding author: purbowatigz@gmail.com 
are appropriate for the baby's developmental stage. The use of mashed food for a long time is not recommended. Thick food should not be given later than 8 to 10 months and have to be given with denser texture [6].

Baby porridge is the primary type of complementary feeding because it contains complete nutrients; the number of servings and the density level could be adjusted to the age. Instant porridge is chosen because it does not require a long time the cook. In addition, the instant porridge aims to extend the shelf life and facilitate packaging and serving. Food ingredients of homemade porridge could be varied according to availability and easily accessible. Local Indonesian food ingredients such as red beans and oyster mushrooms could be used as ingredients. Besides being easy to access, these ingredients also contain nutrients appropriate to meet the baby's needs.

Red bean (Phaseolus vulgaris L.) is a type of vegetable protein source. Every $100 \mathrm{~g}$ of red beans contains $314 \mathrm{kcal}$ of energy, $22.1 \mathrm{~g}$ of protein, $1.1 \mathrm{~g}$ of fat, $56.2 \mathrm{~g}$ of carbohydrates, 4 grams of fiber, $502 \mathrm{mg}$ of calcium, $429 \mathrm{mg}$ of phosphorus $10.3 \mathrm{mg}$ of iron [7]. Without epidermis, red bean seeds contain $21.75 \%$ protein, and its epidermis contains only $5.97 \%$ [8]. Several researchers have previously investigated the formulation of complementary food from red bean flour and mung bean flour and studied instant porridge's chemical and physical characteristics made from glutinous corn and red bean flour $[9,10]$. The addition of red beans to cream soup products increases the protein content and is organoleptically accepted [11].

Oyster mushroom (Pleurotus ostreatus) is a food ingredient because non-toxic mushroom and could be eaten. Oyster mushrooms have a high nutritional content, especially protein, fiber, and iron, but low in carbohydrates, fat, and energy. Every 100 grams of fresh oyster mushrooms contains 30 calories of energy, 3.5 grams of protein, 0.2 grams of fat, 4 grams of carbohydrates, 2.4 grams of fiber [7]. Oyster mushrooms have a similar texture and taste to chicken meat. Most Indonesian people like the taste of oyster mushrooms because of their distinctive taste. The delicious taste of oyster mushrooms could increase the added value of processed products. Adding oyster mushrooms to baby porridge is expected to increase the nutritional value and could be accepted organoleptically by infants. The results of Siyame et al. stated that baby porridge from a mixture of oyster mushroom flour and corn had good sensory value [12]. The addition of oyster mushrooms increases the protein and fiber content of the porridge.

Based on this background, it is necessary to study the formulation of instant baby porridge from red beans and oyster mushrooms as complementary foods. This study aims to determine the level of preference (hedonic test) and nutrient content (carbohydrate, fat, protein, fiber) in the formula of instant baby porridge from red beans and oyster mushrooms.

\section{Method}

The research design was quasi-experimental using a completely randomized design (CRD). There are three formulas of instant porridge with a composition ratio of rice flour and red bean flour in formula 1 (F1), which is 60:40, formula 2 (F2) is 70:30, and formula 3 (F3) 80:20 that can be seen in Table 1. Consider determining the formula, namely the nutritional content of rice flour as a source of carbohydrates and red bean flour as a source of protein. All formulas added 1 gram of dried oyster mushrooms. The three instant porridge formulas were tested for the level of preference. Then the formula with the highest score for the level of preference was tested for the nutritional content of carbohydrates, protein, fat, and fiber. This study uses human subjects as panellists for the preference test. It has obtained approval from the Medical/Health Research Bioethics Commission, Faculty of Medicine, University of Sultan Agung Semarang with number 10/I/2021/Bioethics Commission. This study will be conducted in 2021 . 
Instant porridge is made at the Food Laboratory of Ngudi Waluyo University. The ingredients used to make instant porridge are rice flour, red bean flour, oyster mushrooms, chicken meat, carrots, leeks, celery leaves, butter, garlic powder, chicken stock. The tools used are cabinet drying, pans, knives, cutting boards, and stoves. How to make instant porridge as follows: make dry ingredients for oyster mushrooms, chicken meat, carrots, leeks, and celery cut into small cubes and then dried in a drying cabinet at $500 \mathrm{C}$ for 3 hours. Make a porridge dough by mixing the ingredients of rice flour, flour, red beans, garlic powder, and chicken stock, then cook on low heat while stirring until the dough thickens and all the broth is absorbed. The dough was smeared on aluminium foil and then dried in a drying cabinet at $600 \mathrm{C}$ for 4 hours. The dry porridge dough is removed from the aluminium foil and crushed into small pieces. The composition of instant baby porridge formula is as follows:

Table 1. The composition of instant porridge formula.

\begin{tabular}{|c|c|c|c|}
\hline Ingredients & F1 & F2 & F3 \\
\hline Rice flour (g) & 12.6 & 14.7 & 16.8 \\
\hline Red bean flour (g) & 8.4 & 6.1 & 4.2 \\
\hline $\begin{array}{c}\text { Dried oyster } \\
\text { mushrooms (g) }\end{array}$ & 1 & 1 & 1 \\
\hline Butter (g) & 5 & 5 & 5 \\
\hline Garlic powder (g) & 0.25 & 0.25 & 0.25 \\
\hline Chicken broth (cc) & 200 & 200 & 200 \\
\hline Chicken meat (g) & 2.5 & 2.5 & 2.5 \\
\hline Dried carrots (g) & 1 & 1 & 1 \\
\hline Dried leek + celery (g) & 0.5 & 0.5 & 0.5 \\
\hline
\end{tabular}

The instant baby porridge serving is by dissolving one serving of porridge ( 25 grams) with $300 \mathrm{cc}$ of chicken stock in a saucepan, then heat and stir until cooked. One serving of dry instant porridge ( 25 grams) could become 50 grams of ready-to-eat porridge.

The level of preference for instant porridge formula was tested on 25 moderately trained panellists (the baby's mother). The scoring method for the four product components, including texture, taste, colour, and flavour. The assessment score is $1-5,1=$ immensely dislike, 2 = dislike, $3=$ normal, $4=$ like, 5 = very like, as a parameter to determine an impression of a stimulus caused by the product. Data was collected using a questionnaire.

Carbohydrate, protein, fat, and fiber content were analysed at the Food ChemistryBiochemistry Laboratory, Faculty of Agricultural Technology, University of Semarang. The protein, fat, and fiber content were analysed using the AOAC 2005 method, while the carbohydrate content was calculated by difference. 


\section{Results and discussion}

Organoleptic test or senses or sensory evaluation is a testing procedure done by utilizing the five senses of humans to evaluate the texture, colour, scent, and flavour of food, beverage, and drug products. This test has an essential role in product development. Sensory evaluation is conducted to assess the desired changes on particular product or ingredients, identify the area in the interest of product development, evaluate the competitors' products, observe the changes during the process and the conservation, and provide the data which is required to promote the product [13].

Organoleptic test or the level of preference test includes the components of texture, taste, colour and scent in each sample in formula 1. The ratio of rice flour: red bean flour is 60 : 40 , formula 2 is $70: 30$, and formula 3 is $80: 20$. The results of the preference test can be seen in Figure 1.

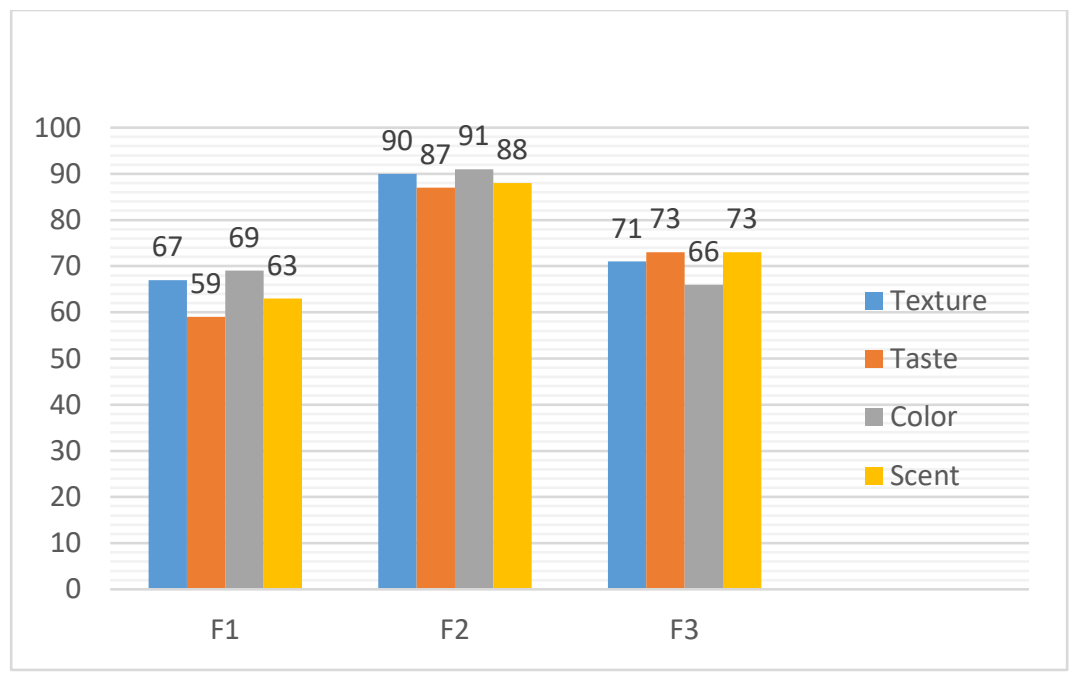

Fig. 1. Organoleptic test score total of instant baby porridge.

Formula 1 got the lowest hedonic test score. Panellists stated that they did not like and intensely disliked the texture as much as $44 \%$, on the taste as much as $51 \%$, on the colour as much as $32 \%$, and on the scent as much as $60 \%$. This is because formula 1 has a coarse texture, is less thick, and unpleasant taste and scent. Coarse texture, not thick, and unpleasant taste comes from red bean flour, the most abundant of the other formulas. Shimelis et al.(2006) stated that the high content of components other than carbohydrates and starch in material, especially protein and fat content, will affect the swelling power and gelatinization properties so that the viscosity of the material will decrease [14].

Formula 2 got the highest hedonic test score. Most panellists stated that they liked and liked the texture, taste, colour and scent of porridge with formula 2. According to the panellists, formula 2 was the most delicious and acceptable to babies. The hedonic test results showed that the panellists did not like formula 3 instant baby porridge. Panellists who did not like the texture of formula 3 were $28 \%, 24 \%$ of panellists did not like it in terms of taste, and $46 \%$ and $32 \%$ of panellists did not like it in terms of colour and scent. Formula 3 has a mushy texture and a blander taste. Formula 3 contains the lowest red bean flour, more rice flour. All baby porridge formulas are added with the same amount of oyster mushrooms, so the savoury taste of oyster mushrooms enhances the taste of the porridge. Previous research on the effect of the addition of oyster mushroom (Pleurotus ostreatus) on nutrient composition and sensory acceptation of selected wheat and rice-based products showed that mushroom-based 
rice porridge had a significantly higher value of odour attribute as compared to control, with rice porridge added with $6 \%$ oyster mushroom powder received the highest score [15].

Formula 2 as the most preferred formula was analyzed for carbohydrate, protein, fat, and fiber content for three repetitions and then averaged.

Table 2. The nutritional content of instant baby porridge and the nutrient needs of infant aged 6-11 months.

\begin{tabular}{|c|c|c|c|}
\hline Nutrient & $\begin{array}{c}\text { Nutritional content of } \\
\text { instant baby porridge (F2) } \\
\text { per serving (25 grams) }\end{array}$ & $\begin{array}{c}\text { Nutritional needs of } \\
\text { infants aged 6-11 months } \\
\text { (RDA 2019) }\end{array}$ & $\begin{array}{c}\% \\
\text { adequacy } \\
\text { of nutrients }\end{array}$ \\
\hline Carbohydrate & $39.2(\mathrm{~g})$ & $105(\mathrm{~g})$ & $37.9 \%$ \\
\hline Protein & $6.1(\mathrm{~g})$ & $15(\mathrm{~g})$ & $40.1 \%$ \\
\hline Fat & $1(\mathrm{~g})$ & $35(\mathrm{~g})$ & $2.9 \%$ \\
\hline Fiber & $1.1(\mathrm{~g})$ & $11(\mathrm{~g})$ & $10 \%$ \\
\hline
\end{tabular}

Table 2 shows the average nutritional content of instant baby porridge (F2), the nutritional needs of infants aged 6-11 months, and the percentage of nutritional adequacy. Each serving of instant baby porridge (F2) 25 grams contains 39.2 grams of carbohydrates, 6.1 grams of protein, 1 gram of fat, 1.1 grams of fiber. When compared with the nutritional needs of infants aged 6-11 months (RDA 2019) [16], instant baby porridge formula 2 can meet the nutritional needs of infants, including the needs of carbohydrates, protein, fat, and fiber, respectively $37.3 \%, 40.1 \%, 2.9 \%$, and $10 \%$. The carbohydrate and protein content in the porridge is in the high category because it meets more than $35 \%$ of the baby's needs, while the fat and fiber content is low and does not meet the baby's needs because it meets less than $15 \%$ of the needs.

Adequate intake of energy and protein affects the growth and development of children and the optimal immune system. Macronutrients can be considered the main components of different tissues. They constitute the total amount of caloric intake, meaning the principal energy source of the human body; they are mainly distinguished in carbohydrates, proteins, and lipids [17]. Low energy and protein intake will put children at risk for developmental delays. There is a significant relationship between energy and protein adequacy of local MPASI with development [18]. Breast-fed and mixed-fed infants had a more varied diet as compared to formula-fed infants. Understanding these primary food sources during complementary feeding can inform local dietary recommendations and policies [19].

Previous research stated that $30 \%$ red bean flour in making baby porridge had the highest protein content $(16.37 \%)$ and energy $(103.4 \mathrm{cal})$. It is recommended that babies eat 165 grams of porridge per day to meet their nutritional needs [20]. Based on its contribution to the Nutritional Adequacy Ratio for children aged 6-11 months, this formula 2 instant porridge with the addition of red bean flour and oyster mushrooms can be used as a complementary food for breast milk that contains high protein. It is recommended to consume 3 servings a day. It is necessary to improve the formulation to increase the fat content by adding a dose of butter to manufacture porridge dough. In addition, it is also necessary to add a dose of dried oyster mushrooms to increase the fiber content to meet product quality requirements, according to SNI. According to SNI for Instant Powdered MP ASI, the nutritional content per 100 grams of ready-to-eat porridge is 30 grams of carbohydrates, 8-22 grams of protein, 6-15 grams of fat, serat 5 grams of fiber [21]. 


\section{Conclusion}

Instant baby porridge with the addition of red bean flour and oyster mushrooms (F2) could be used as a complementary food to meet the nutritional needs of babies. However, this formula needs to improve to increase the fat by adding a dose of butter and a dose of dried oyster mushrooms to increase the fiber.

Thank LPPM UNW for funding this research through the Applied Research program 2020.

\section{References}

1. K. F. Michaelsen, L. Grummer-Strawn, and F. Bégin, Matern. Child Nutr.13 (2017)

2. Departemen Kesehatan RI, Pedoman Umum Pemberian Makanan Pendamping Air Susu Ibu (MP-ASI) Lokal (Departemen Kesehatan RI, Jakarta, 2006)

3. World Health Organization, "Report of the Commission on Ending Childhood Obesity," (2016)

4. R. Masuke et al., PLoS One, 16 (2021)

5. M. A. Abeshu, A. Lelisa, and B. Geleta. Front. Nutr. 3 (2016)

6. M. Fewtrell et al., JPGN, 64, 1 (2017)

7. Kementerian Kesehatan RI, Tabel Komposisi Pangan Indonesia Tahun 2017 (Kementerian Kesehatan RI, Jakarta, 2018)\

8. S. H. Kusumah, R. Andoyo, and T. Rialita, SciMedicine J. 2 (2020)

9. D. N. Surahman, Y. Taufik, D. P. Nudianti2, and T. Rahman, Formulation and production costs optimization of complementary food for breast milk from red sorghum flour (sorghum bicolor l.), red bean flour (phaseolus vulgaris l.) and mungbean flour (phaseolus radiatus l.) using linear programming method, in IOP Conference Series: Earth and Environmental Science, 2021, Virtual Education (2021)

10. S. Palijama, R. Breemer, and M. Topurmera, AGRITEKNO J. Teknol. Pertan. 9 (2020)

11. F. Rozi, S. A. Marliyati, and C. M. Kusharto, agriTECH, 40 (2020)

12. R. Siyame, N. Kassim, and E. Makule, Hindawi Int. J. Food Sci. (2021)

13. R. Tanone and H. B. Prasetya, Int. J. Interact. Mob. Technol. 13 (2019)

14. E. A. Shimelis, M. Meaza, and S. K. Rakshit, Agric. Enginering Int. 8 (2006)

15. M. S. Aishah and W. I. Wan Rosli, Int. Food Res. J. 20 (2013)

16. Peraturan Menteri Kesehatan Republik Indonesia Nomor 28 Tahun 2019, Angka Kecukupan Gizi Yang Dianjurkan Untuk Masyarakat Indonesia (2019)

17. G. Savarino, A. Corsello, and G. Corsello, Ital. J. Pediatr. 47 (2021)

18. Y. Fitriani, Firdawati, and G. Lubis, J. Kesehat. Andalas, 8 (2019)

19. S. X. Lim et al., Int. J. Environ. Res. Public Heal. 15 (2018)

20. R. Damanik, L. Kustiyah, S. M. Atmojo, and S. Yuliani, J. Media Gizi dan Kel. 24 (2000)

21. Badan Standarisasi Nasional, SNI: 01-7111.1-2005. Makanan Pendamping Air Susu Ibu (MP-ASI) - Bubuk Instan. (Dewan Standar Nasional Indonesia, Jakarta, 2005) 